\title{
Exchange rate pass-through to import prices: Evidence from Serbia
}

\author{
Safet Kurtović* \\ Faculty of Management and Business Economics, University of Travnik, Bosnia and Herzegovina
}

Received: 12 May 2018

Revised: 19 November 2018

Accepted: 22 November 2018

\begin{abstract}
In this paper we estimated the degree of exchange rate pass-through (ERPT) into aggregate import prices in Serbia. ERPT was determined by application of single equation, cointegration approach (ARDL model), error correction term (ECM) and VAR Granger Causality tests. We based our research on data from 2008Q1 to 2014Q4. The results of our research show partial pass-through in the short run; in the long run pass-through was not observed. In addition to that, we found that appreciation of the nominal effective exchange rate (NEER) led to significant pass-through asymmetry in the short run.
\end{abstract}

Keywords: import prices; exchange rate pass through; import; long run JEL Classification Codes: F3, F4, F31

\section{Introduction}

During the last few decades, investigation of relation between exchange rate fluctuations and import prices has been given considerable attention in international economics and macroeconomics, from both the theoretical and empirical aspect (Lopez-Villavicencio and Mignon, 2017). According to early research that was based on the law of one price, changes in exchange rate had direct impact on import prices. On the other hand, according to recent research import prices depend on manner of determining a pricing strategy on different markets, i.e. on price mechanism based on margin oscillations in relation to marginal costs and other factors (Beckmann et al, 2014).

During the last three decades, decline of pass-through has been obvious in most of the analyzed cases. The degree of ERPT depends on economic shocks, nominal exchange rate volatility, inflation rate, change in importing country's demand, product substitution, market structure,

\footnotetext{
*E-mail: safetkurtovic71@yahoo.com.

Citation: Kurtović, S. (2019) Exchange rate pass-through to import prices: Evidence from Serbia, Economics and Business Letters, 8(1), 7-16.
}

DOI: $10.17811 / \mathrm{ebl} .8 .1 .2019 .7-16$ 
market competition, economic openness, market integration, market segmentation and aggregate import (Campa and Goldberg, 2002; Campa et al., 2005, Byrne et al., 2010; Lopez-Villavicencio and Mignon, 2017, Kurtovic et al., 2018).

Campa and Goldberg $(2002 ; 2005)$ estimated transmission degree of ERPT into import prices of Euro Area countries. They came to a conclusion that ERPT was high and incomplete in the short run and that it was different from one country to another and from one industry to another. Barhoumi (2006) and Byrne et al., (2010) estimated the degree of ERPT into import prices of emerging and developing countries. They found the developing countries, emerging and Asian economies to have higher EPRT than in the developed ones. Jabar (2009) estimated the degree of ERPT into import prices of the USA in bilateral trade with the EU, Asian countries and Canada. He determined that ERPT was partial for all countries. María-Dolores (2010), Ben Cheikh and Rault (2017) estimated the degree of ERPT into import prices of 12 Euro Area countries and new member states of the EU and Turkey. They found higher ERPT only for the Slovenia and Cyprus.

The main objective of our research is to measure the effect of ERPT on Serbia's import prices. The problem of pass-through is especially important for small open economies that are import-dependent in international exchange. In that sense, Serbia is ranked among transition countries that have traditionally had negative trade balance and are import dependent (Figure 1). Serbia imports the most crude materials, inedible, except fuels, miscellaneous manufactured articles, chemicals and related products, machinery and transport equipment, while most exported miscellaneous manufactured articles, machinery and transport equipment, manufactured goods and animal and vegetable oils (Figures 2-3). In terms of import, the leading trade partners are Italy, Germany, Bosnia and Herzegovina, Romania and the Russian Federation, whilst in terms of export the trade partners are Germany, Italy, the Russian Federation, China and Hungary. Being faced with trade imbalance, Serbian economy lacks competitiveness. Serbia often resorts to currency fluctuation in order to restore its trade balance. It is hence exceptionally important to measure the effect of ERPT into import prices. A low ERPT leads to low inflation. On the other hand, a low ERPT could also cause trade imbalance when there is a requirement to change the import or export composition and impair competitiveness in the international trade exchange. A high ERPT works in the opposite direction. Finally, the evaluation of ERPT is important for restraining inflation pressures and trade imbalance caused by currency fluctuations.

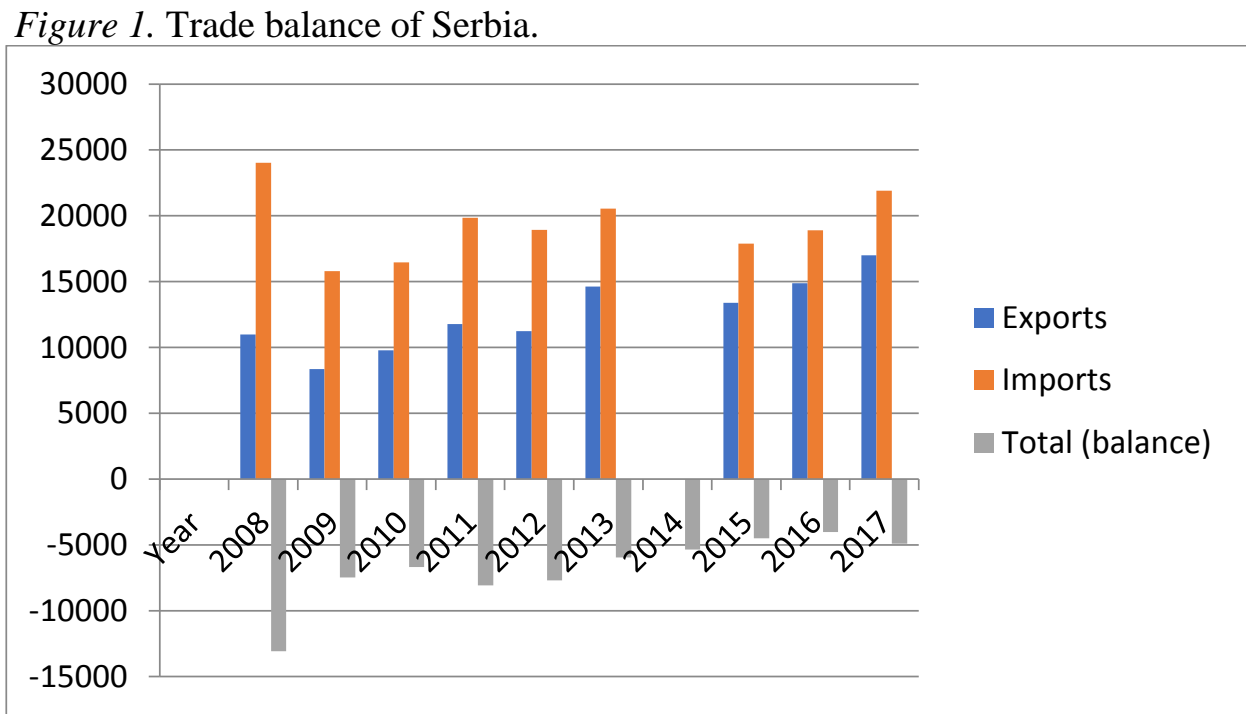

Note: Figure 1 presents data obtained on the basis of data made available by Statistical office of the Republic of Serbia. Source: Author compilation. 
Figure 2. Imports of product by SITC 4.

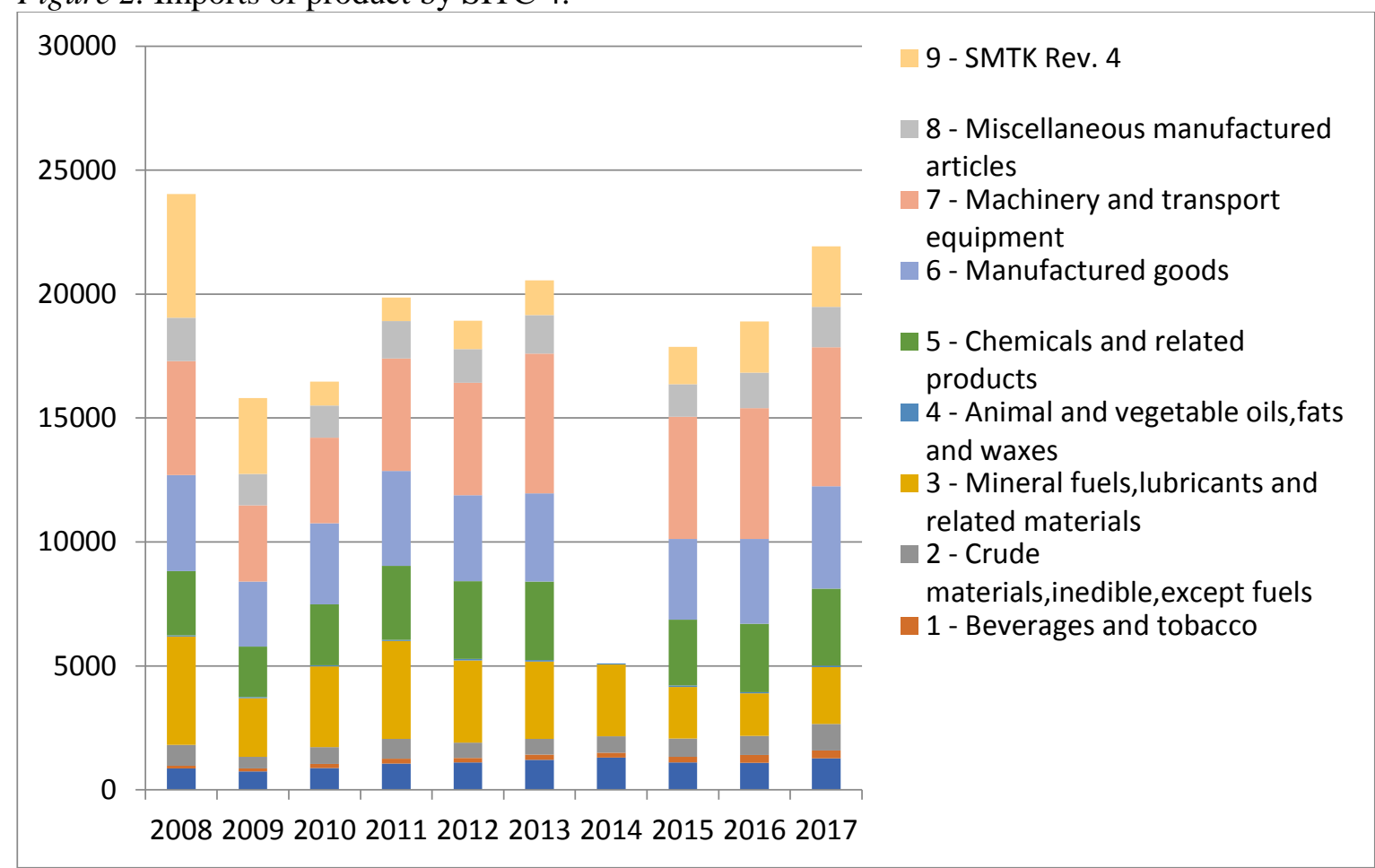

Note: Figure 2 presents data obtained on the basis of data made available by Statistical office of the Republic of Serbia. Source: Author compilation.

Figure 3. Exports of product by SITC 4.

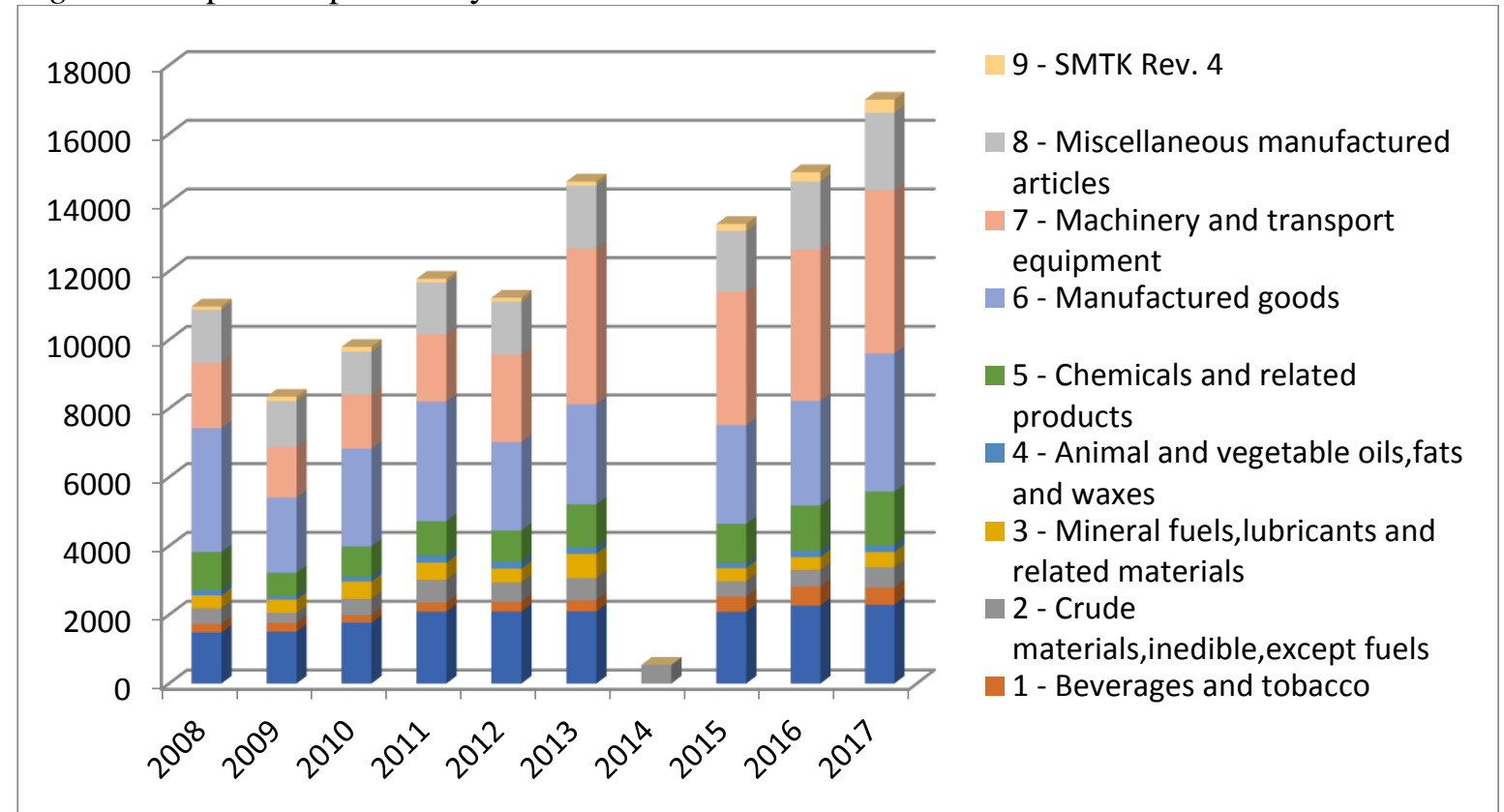

Note: Figure 3 presents data obtained on the basis of data made available by Statistical office of the Republic of Serbia. Source: Author compilation.

The paper has the following structure: part 2 presents some stylized facts; part 3 gives information on applied methodology and database; part 4 presents empirical results; part 5 is a conclusion. 


\section{Some stylized facts}

Prior to and following the great economic crisis in 2007, Serbia had a high inflation rate, a high trade balance deficiency and frequent exchange rate fluctuations. In the period analysed (2008 -2014 ), the average inflation rate amounted to $6.9 \%$. The highest inflation rate $-12.2 \%$ was recorded in 2012.

With a view to decrease its trade imbalance, Serbia has frequently resorted to exchange rate depreciation policies (Figure 4). In the period between 2008 and 2014, Serbia's national currency, the dinar, has depreciated by $27 \%$ against the US dollar.

The highest decrease in import prices was recorded in the period of economic crisis (20072009), which was also the case with other transitional economies of Southeastern Europe. Accordingly, Serbia used NEER depreciation measures so as to reduce the import of goods. Changes in import prices were directly related to the changes in the NEER (Figure 5). Additionally, the decreased domestic production had an impact on the oscillations in import prices, i.e. on the decline of the GDP.

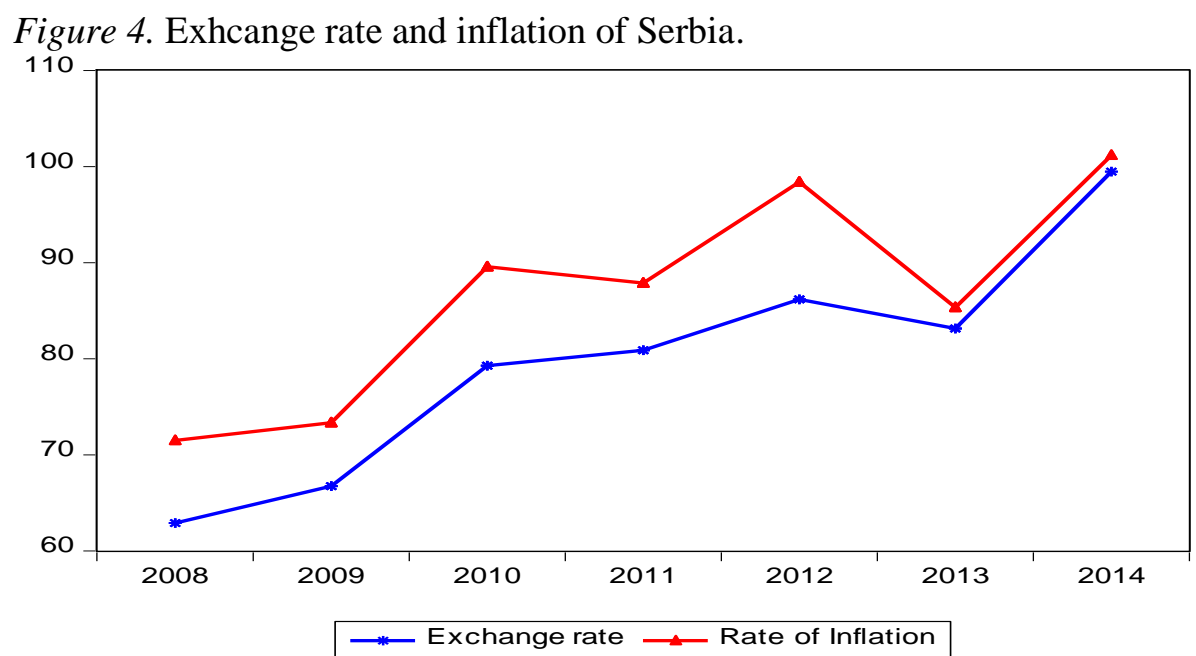

Note: Figure 4 presents data obtained on the basis of data made available by Statistical office of the Republic of Serbia. Source: Author compilation.

Figure 5. NEER and import prices of Serbia.

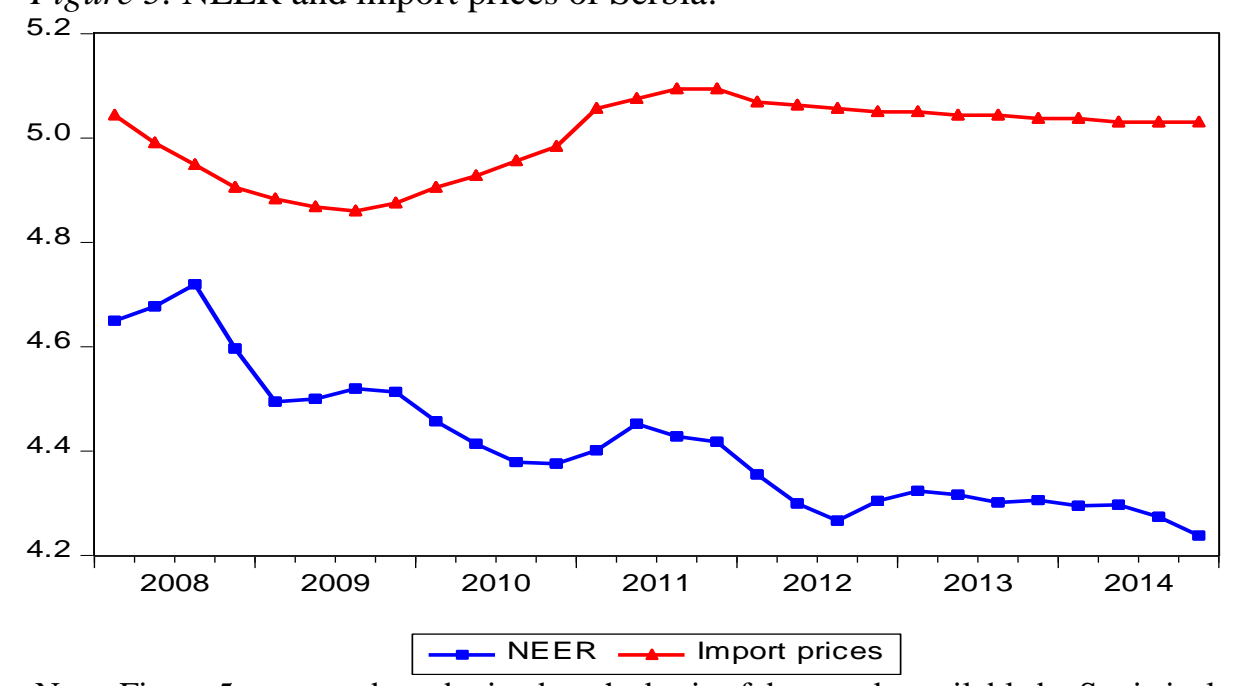

Note: Figure 5 presents data obtained on the basis of data made available by Statistical office of the Republic of Serbia. Source: Author compilation. 


\section{Methodology and data}

\subsection{Empirical model}

The empirical assessment of the ERPT is based widely-used model by Goldberg and Knetter (1997), Campa and Coldber (2002, 2005) and Bailliu and Fujii (2004) (Kurtovic et al., 2018):

$$
\operatorname{lnm} p_{t}^{x, j}=\alpha_{0}+\alpha_{1} \operatorname{lnm} c_{t}^{x, j}+\alpha_{2} \ln e_{i t}+\alpha_{3} \ln \mu_{t}+\varepsilon_{t},
$$

where $\operatorname{lnm} p_{t}^{x, j}$ represents import prices in the local currency and is a function of $\ln e_{i t}$ - the nominal effective exchange rate $\ln m c_{t}^{x, j}$ - marginal foreign costs of production, $\ln \mu_{t}$ - domestic demand, $\varepsilon_{t}$ - the error disturbance term and $\alpha_{0}$ - a constant.

Bearing in mind that depreciation and appreciation cause pass-through fluctuations, we shall introduce a dummy variable and mark the period of appreciation as 1 and the period of depreciation as 0 (Kurtović et al., 2018):

$$
\text { dummy }_{A}=1 \text { if } \Delta e_{i t}<0 \text { and dummy } y_{D}=O \text { if } \Delta e_{i t}>0,
$$

where Dummy $y_{A^{-}}$stands for the exchange rate appreciation, Dummy $y_{D}$ is the exchange rate depreciation and $\Delta e_{i t}$ the exchange rate fluctuation.

By incorporating the dummy variables into the equation (1), we obtain the equation (3) that reflects the asymmetry in fluctuations of currency exchange rates (Kurtovic et al., 2018):

$$
\operatorname{lnm} p_{t}^{x, j}=\alpha_{0}+\alpha_{1} \operatorname{lne}_{i t}+\alpha_{2} \ln _{i t} x d u m m y_{t}+\alpha_{3} \operatorname{lnm} c_{t}^{x, j}+\alpha_{4} \ln \mu_{t}+\varepsilon_{t} .
$$

If the $\alpha_{2}$ coefficient has a positive sign, then the exchange rate depreciation has a greater effect on import prices. Conversely, if $\alpha_{2}$ has a negative sign, then the exchange rate appreciation has a greater effect on import prices (Byrne et al., 2010; Kurtović et al., 2018).

We present the ARDL model using the equation (4):

$$
\begin{gathered}
\Delta \operatorname{lnm} p_{t}^{x, j}=\alpha_{0}+\sum_{i=1}^{l} \alpha_{1, i} \Delta \operatorname{lnm} p_{t-1}^{x, j}+\sum_{i=0}^{l} \alpha_{2, i} \Delta \ln e_{i t-1}+ \\
\sum_{i=0}^{l} \alpha_{3, i} \Delta \ln e_{i t-1} x d u m m y_{t-1}+\sum_{i=0}^{l} \alpha_{4, i} \Delta m c_{t-1}^{x, j}+\sum_{i=0}^{l} \alpha_{5, i} \Delta \mu_{t-1}^{x, j}+ \\
\beta_{1, i} \Delta \operatorname{lnm} p_{t-1}^{x, j}+\beta_{2, i} \Delta \ln e_{i t-1}+\beta_{3, i} \Delta \operatorname{lne}_{i t-1} x d u m m y_{t-1}+\beta_{4,1} \Delta m c_{t-1}^{x, j}+\beta_{5,1} \Delta \mu_{t-1}^{x, j}+ \\
\varepsilon_{t .}
\end{gathered}
$$

\subsection{Data}

We used quarterly data from $2008 Q 1$ to 2014 Q4. Import unit value index $(2010=100)-$ measures average changes of the value of imported goods. Data on the import prices $(2010=100)$ were obtained from the World Bank data base (Kurtovic et al., 2018). The nominal effective exchange rate $(2010=100)$ is the weighted average of the bilateral nominal exchange rate of the dinar against the currency basket (dollars and Euros). The data on nominal effective exchange rate $(2010=100)$ were obtained from the data bases of the National Bank of Serbia. As for Serbia, the data were obtained on grounds of the producer price index (PPI), representing a weighted price index calculated at wholesale or producer's level. The PPI is also known as the wholesale price index. Marginal foreign costs of production are calculated by eliminating the nominal effective exchange rate and labour wages or the producer price index from the relative effective exchange rate: $M C=($ REER x WPI/PPI)/NEER (Byrne et al., 2010; Kurtovic et al., 2018). The data were obtained from the data bases of Statistical Office of the Republic of Serbia. We use the real GDP of the importing country (Gross domestic product $2010=100$ ) which is used as a proxy for total demand. The data on domestic demand were obtained from the data bases of Statistical Office of the Republic of Serbia (Kurtovic et al., 2018). 


\section{Empirical results}

Table 1 shows the results for ADF and PP unit root tests. All variables are stationary at level I(1), i.e.by introduction of the first difference at $1 \%$ and $5 \%$ statistics significance level. Based on our results, we dismiss the null hypothesis that data are not stationary, i.e. that data series are integrated at level $\mathrm{I}(0)$ and $\mathrm{I}(1)$, which means that we can apply ARDL approach.

Table 1. Unit Root Test.

\begin{tabular}{l|rrr|rrr}
\hline \hline & \multicolumn{3}{|c|}{ ADF } & \multicolumn{3}{|c}{ PP } \\
Variable & $\mathbf{c}$ & $\mathbf{c , t}$ & First Diff.(1) & $\mathbf{c}$ & $\mathbf{c , t}$ & First Diff.(1) \\
\hline $\begin{array}{c}\text { Import } \\
\text { prices }\end{array}$ & $-3.09 * *$ & $-3.29 * * *$ & $-6.68 *$ & $-1.47 * * *$ & $-2.37 * * *$ & $-6.37 *$ \\
NEER & $-1.43 * * *$ & $-4.30 * *$ & & $-1.32 * * *$ & $-2.05 * * *$ & $-6.65 *$ \\
$\begin{array}{c}\text { Marginal } \\
\text { costs }\end{array}$ & $-2.04 * * *$ & $-2.32 * * *$ & $-8.13 *$ & $-2.03 * * *$ & $-2.32 * *$ & \\
$\begin{array}{c}\text { Domestic } \\
\text { demand }\end{array}$ & $-2.70 * * *$ & $-2.47 * * *$ & $-5.78 *$ & $-3.10 * *$ & $-3.14 * * *$ & $-6.41 *$ \\
\hline \hline
\end{tabular}

Note: $^{* * *}$, and $^{* * *}$ show significance levels at 1\%,5\% and 10\% respectively. Source: Author compilation.

Table 2 presents the results of F-statistics. We obtained the optimal number of lags from 1 to 3 based on selection of Akaike Information Criterion (AIC) and Schwarz Bayesian Criterion (SBC) values. F-statistics is $5.88 \%$ and it is above Bounds (upper bounds) statistics, which means that we dismiss the null hypothesis that there is no cointegration among variables.

Table 2. The results of the F-test.

\begin{tabular}{lrrr}
\hline \hline Lag length & F-statistics & AIC & SC \\
\hline \hline 1 & 3.21 & -19.15 & -13.19 \\
2 & 1.61 & -20.59 & -17.91 \\
3 & $5.88 *$ & $-21.99 *$ & $-18.09 *$ \\
\hline Source: Author compilation.
\end{tabular}

Table 3 presents the results of long-run elasticity of variables. Nominal effective exchange rate (NEER) is not significant and does not influence the increase of aggregate import prices, i.e. there is no pass-through. Finally, exchange rate asymmetry is significant at $10 \%$ level, i.e. it appeared based on appreciation of NEER.

Table 3. Long-run estimates

\begin{tabular}{lrrrr}
\hline \hline Variable & Coefficient & Std. Error & t-Statistic & Prob. \\
\hline \hline lNEER & 0.25 & 0.18 & 1.40 & 0.20 \\
ldomestic demand & -0.20 & 0.75 & -0.27 & 0.78 \\
lmarginal costs & 0.98 & 0.41 & 2.34 & $0.05 *$ \\
Dummy & 0.09 & 0.04 & 2.28 & 0.06 \\
\hline \hline
\end{tabular}

Note: ${ }^{* * *}$, and ${ }^{* * *}$ show significance levels at $1 \%, 5 \%$ and $10 \%$ respectively. Source: Author compilation. 
Table 4 presents the results of short-run elasticity of variables. NEER is significant in the short run, on the second lag, at 5\% level, i.e. it influences the decrease of aggregate import prices in Serbia. NEER coefficient in the short run equals $-0,31 \%$, which is a low value, smaller than $1 \%$, which means that there is a partial pass-through in the short run. The LCP (local currency pricing) strategy hypothesis cannot be rejected. The import prices are denominated in the currency of the importing country and hence the ERPT is low and the changes of the exchange rate have no effect on import prices. Each NEER apreciation above $1 \%$ leads to $-0,31 \%$ decrease of aggregate import prices. Partial pass-through occurs because import prices are denominated in importer currency so that each $1 \%$ change of nominal exchange rate affects the change of import price denominated in importer currency.

Table 4. Short-run estimates and ECM (-1) - ARDL (3, 1, 3, 3)

\begin{tabular}{|c|c|c|c|c|}
\hline Variable & $\overline{\text { Coefficient }}$ & Std. Error & t-Statistic & Prob. \\
\hline$\Delta l(N E E R)$ & 0.01 & 0.07 & -0.22 & 0.82 \\
\hline$\Delta l(N E E R(-1))$ & 0.07 & 0.07 & 0.96 & 0.36 \\
\hline$\Delta l(N E E R(-2))$ & -0.31 & 0.09 & 3.31 & $0.01 * *$ \\
\hline$\Delta l($ domestic demand $)$ & 1.22 & 0.30 & 4.06 & $0.00 *$ \\
\hline$\Delta l($ marginal costs $)$ & 0.37 & 0.07 & 4.83 & $0.00 *$ \\
\hline$\Delta l($ marginal costs $(-1))$ & -0.32 & 0.07 & -4.22 & $0.00 *$ \\
\hline$\Delta l($ marginal costs $(-2))$ & -0.22 & 0.06 & -3.75 & $0.00 *$ \\
\hline$\Delta$ (dummy) & 0.01 & 0.01 & 1.61 & 0.15 \\
\hline$\Delta($ dummy $(-1))$ & -0.04 & 0.01 & -4.72 & $0.00 *$ \\
\hline$\Delta($ dummy $(-2))$ & -0.01 & 0.01 & -1.36 & 0.21 \\
\hline C & 0.44 & 0.06 & 6.81 & $0.00 *$ \\
\hline $\operatorname{ECM}(-1)$ & -0.85 & 0.12 & -6.79 & $0.00 *$ \\
\hline Wald test & $\begin{array}{r}3.48 \\
0.00 *\end{array}$ & & & \\
\hline$L M x_{S C}^{2}$ & 3.389 & & & \\
\hline Heteroscedasticity $x_{N}^{2}$ & $\begin{array}{r}2.998 \\
0.07\end{array}$ & & & \\
\hline Normality $x_{F C}^{2}$ & $\begin{array}{r}0.274 \\
0.87\end{array}$ & & & \\
\hline RESET test & $\begin{array}{l}0.235 \\
0.812\end{array}$ & & & \\
\hline CUSUM & Stable & & & \\
\hline CUSUMSQ & Stable & \multirow{4}{*}{\multicolumn{2}{|c|}{$\begin{array}{l}\text { S.D. dependent var } \\
\text { Durbin-Watson stat }\end{array}$}} & \\
\hline Adjusted R-squared & 0.79 & & & 0.07 \\
\hline$F$-statistic & 76.37 & & & 2.06 \\
\hline $\operatorname{Prob}(F$-statistic $)$ & 0.00 & & & \\
\hline
\end{tabular}

,**, and ${ }^{* * * *}$ show significance levels at $1 \%, 5 \%$ and $10 \%$ respectively.

Source: Author compilation

Also, there is a short-run pass-through asymmetry due to NEER apreciation, i.e. asymmetry was observed on the second lag and is significant at 1\% level. Finally, we introduced ECM (1) model in the short run which shows the speed of correction in establishing a long-run balance after disruption or shocks of import prices. ECM(-1) has a high negative expected value $-0,85 \%$ that is significant at $1 \%$ level. In the end, LM test, heteroscedasticity test, REST and CUSUM 
and CUSUMSQ tests show that there are complete stability and no functional limitations (see Figure 6).
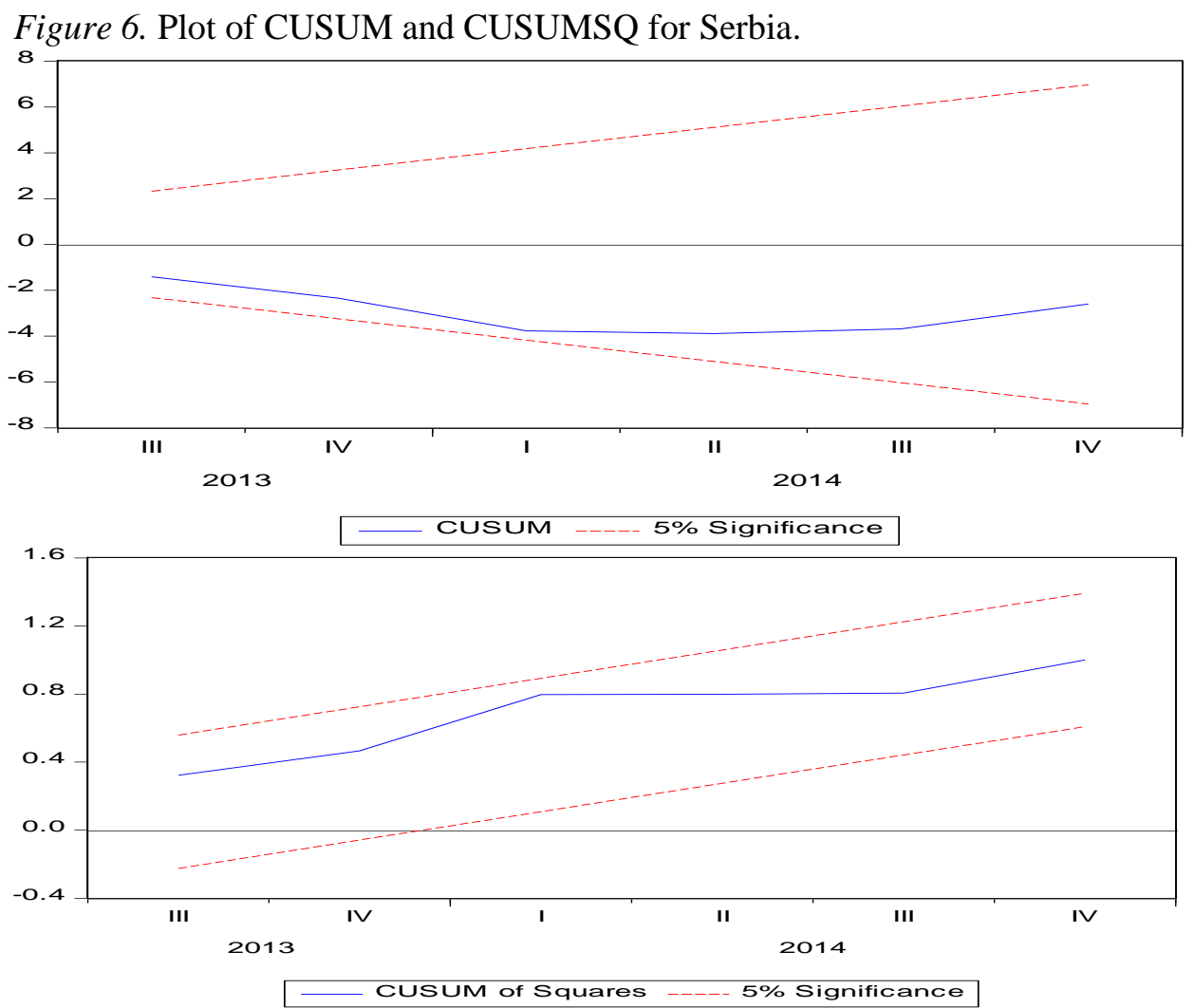

Source: Author compilation.

Table 5 presents the conclusion that, based on VAR argumented Granger causality test, there is no long-run causality among variables. However, in the short run there is causality only between marginal costs and import prices, NEER and domestic demand. VAR argumented Granger causality confirms a one-way relationship between marginal cost and import prices, NEER and domestic demand, while there is no two-way causality.

Table 5. VAR Granger Causality/Block Exogeneity Wald Tests.

\begin{tabular}{lrrrrr}
\hline $\begin{array}{l}\text { Dependent } \\
\text { variable }\end{array}$ & $\begin{array}{r}\Delta \text { lImport } \\
\text { prices }\end{array}$ & $\Delta$ lNEER & $\begin{array}{r}\Delta \text { IDomestic } \\
\text { demand }\end{array}$ & $\begin{array}{r}\Delta \text { lMarginal } \\
\text { costs }\end{array}$ & $\Delta$ Dummy \\
\hline \hline$\Delta$ lImport & - & 2.19 & 0.52 & 0.40 & 2.49 \\
prices & & $(0.53)$ & $(0.91)$ & $(0.94)$ & $(0.47)$ \\
$\Delta$ lNEER & 2.45 & - & 0.53 & 1.54 & 0.94 \\
& $(0.48)$ & & $(0.91)$ & $(0.67)$ & $(0.81)$ \\
$\Delta$ lDomestic & 2.26 & 0.13 & - & 1.39 & 0.36 \\
demand & $(0.51)$ & $(0.98)$ & & $(0.70)$ & $(0.94)$ \\
$\Delta$ lMarginal & 49.90 & 53.18 & 8.28 & - & 6.04 \\
costs & $(0.00) *$ & $(0.00) *$ & $(0.04) *$ & & $(0.10)$ \\
$\Delta$ Dummy & 3.35 & 2.96 & 6.23 & 18.75 & - \\
& $(0.34)$ & $(0.39)$ & $(0.10)$ & $(0.78)$ & \\
\hline \hline
\end{tabular}

Note: ${ }^{* * *}$, and ${ }^{* * *}$ show significance levels at $1 \%, 5 \%$ and $10 \%$ respectively. Source: Author compilation. 
Table 6 lists the results of the Chow and Andrews tests providing a verification of exogenously and endogenously determined breakpoints. The results of both tests have shown that there was a breakpoint and that all the assessed coefficients were statistically significant. Hence, the structural stability hypothesis can be rejected. The exogenous and endogenous factors affecting the occurrence of the breakpoint are the great economic crisis of 2007 and negative structural problems Serbia's economy is facing.

Table 6. Breakpoint tests.

\begin{tabular}{lrc}
\hline \hline & F-statistic & Prob. \\
\hline Chow Breakpoint & 3.32 & $0.05 * *$ \\
Quandt-Andrews & 27.42 & $0.00 *$ \\
Break point & $2008: 3$ & \\
\hline \hline
\end{tabular}

Note: $*, * *$, and $* * *$ show significance levels at $1 \%, 5 \%$ and $10 \%$, respectively. Source: Author compilation.

Table 7 presents the results of the robustness regression. The results of assessed coefficients show that there is a cointegration between the variables and robustness results, i.e. the statistical significance is determined at $1 \%$ and $5 \%$ levels.

Table 7. Robustness check.

\begin{tabular}{lrrr}
\hline \hline & Coefficient & Statistic & Prob. \\
\hline \hline$\Delta$ lNEER & -0.65 & -7.85 & $0.00 *$ \\
$\Delta$ lDomestic demand & 1.80 & 1.90 & $0.05 * *$ \\
$\Delta$ lMarginal costs & 0.71 & 8.08 & $0.00 *$ \\
Adj.R-sq. & 0.78 & 0.28 & 0.75 \\
& & & \\
\hline
\end{tabular}

Note: $* * *$, and $* * *$ show significance levels at $1 \%, 5 \%$ and $10 \%$, respectively.

Source: Author compilation

\section{Concluding remarks}

Serbia's monetary strategy is to use the managed floating exchange rate and inflation targeting. Monetary authorities intervene on the currency market in order to maintain stability from shortterm currency fluctuations, the level of currency reserves and financial and price stability. On the other hand, the nominal effective exchange rate represents the weighted average of the bilateral nominal exchange rate of the dinar against the currency basket comprised of dollars and Euros. The main factors leading to the changes in the nominal effective exchange rate are caused by the fluctuation of the euro and the dollar against the dinar.

Measuring results have shown that in the short run there is a partial pass-through that equals $-0,31 \%$, while long-run pass-through was not confirmed. In the short run, partial pass-through is the result of exchange rate appreciation leading to a decrease in import prices. Foreign exporters use the LCP strategy which leads to incomplete or low pass-through as the import prices are denominated in the currency of the importer.

Finally, we found a negligible pass-through asymmetry $-0,04 \%$ in the short run. Pass-through asymmetry occurs as a result of NEER apreciation in the short run. 
We hope that the results of our research will help economic policy makers to improve their understanding of the transmission mechanism. The exchange rate appreciation leads to a decrease in inflation and import prices. The application of the LCP strategy means that the prices are denominated in the importing country's currency and that the ERPT is therefore low and the exchange rate oscillations have no effect on import prices. Frequent currency fluctuations are not recommended as they lead to the deviation from the law of one price. It is therefore that the policy makers should re-examine their monetary policies and the exchange rate regime as instruments used to suppress inflation and trade imbalance.

Moreover, this paper represents a good basis for future research that will include macroeconomic factors that explain ERPT into import and consumer prices in Serbia, and also into application of Johnsen cointegration, VECM and Impulse Response Function.

\section{References}

Bailliu, J. and Fujii, E. (2004) Exchange Rate Pass-Through and the Inflation Environment in Industrialized Countries: An Empirical Investigation, Staff Working Paper No. 2004-21. Bank of Canada.

Barhoumi, K. (2006) Differences in long run exchange rate pass-through into import prices in developing countries: An empirical investigation, Economic Modelling, 23, 926-951. https://doi.org/10.1016/j.econmod.2006.04.006

Ben Cheikh, N. and Rault, C. (2017) Investigating First-Stage Exchange Rate Pass-Through: Sectoral and Macro Evidence from Euro Area Countries, IZA Discussion Paper No. 10555. Institute for the Study of Labor (IZA), Bonn.

Byrne, P. J., Chavali, A. S. and Kontonikas, A. (2010) Exchange Rate Pass Through To Import Prices: Panel Evidence From Emerging Market Economies, SIRE Discussion Papers No. 2010-46, Scottish Institute for Research in Economics (SIRE).

Campa, J. and Goldberg, L. S. (2002) Exchange Rate Pass-Through into Import Prices: A Macro or Micro Phenomenon?, Working Paper No. 8934, National Bureau of Economic Research, Cambridge, MA.

Campa, J., Goldberg, L. S. and González-Mínguez, J. M. (2005) Exchange-Rate Pass-Through to Import Prices in the Euro Area, Working Paper No. 11632, National Bureau of Economic Research, Cambridge, MA.

Goldberg, P. K. and Knetter, M. M. (1997) Goods Prices and Exchange Rates: What Have We Learned?, Journal of Economic Literature, 35(3),1243-1272.

Jabara, C. L. (2009) How Do Exchange Rates Affect Import Prices? Recent Economic, Working Paper No. ID-21. Washington, DC.

Kurtovic, S., Siljković, B., Denić, N., Petković, D., Mladenović, S. S. and Milovančević, I. (2018) Exchange rate pass-through and Southeast European economies, Statistical Mechanics and its Applications, 3, 400-409. DOI 10.1016/j.physa.2018.03.005

Lopez-Villavicencio, A. and Mignon, V. (2017) Explaining exchange rate pass-through to import prices: Does globalization matter?. http://crief.labo.univ-poitiers.fr/wpcontent/uploads/sites/127/2017/04/Lopez_papier.pdf (Accessed December 12, 2017).

María-Dolores, R. (2010) Exchange rate pass-through in New Member States and candidate countries of the EU, International Review of Economics and Finance, 19, 23-35. https://doi.org/10.1016/j.iref.2009.02.009

Özyur, S. (2016) Has the exchange rate pass through recently declined in the euro area?, Working Paper Series No. 1955, Leibniz Information Centre for Economics, European Central Bank. 